\title{
Expression Levels of the Uridine-Cytidine Kinase Like-1 Protein As a Novel Prognostic Factor for Hepatitis C Virus- Associated Hepatocellular Carcinomas
}

\author{
A. Buivydiene ${ }^{1 *}$, V. Liakina ${ }^{2,3}$, J. Valantinas ${ }^{1}$, J. Norkuniene ${ }^{4,5}$, E. Mockiene ${ }^{6,7}$, S. Jokubauskiene ${ }^{8,9}$, \\ R. Smaliukiene9 , L. Jancoriene ${ }^{10}$, L. Kovalevska ${ }^{11}$, E. Kashuba ${ }^{11,12 *}$ \\ 'Vilnius University, Clinic of Gastroenterology, Nephrourology and Surgery, Centre of Hepatology, \\ Gastroenterology and Dietetics, Vilnius, Lithuania \\ ${ }^{2}$ Vilnius University, Center of Hepatology, Gastroenterology and Dietetics, Vilnius, Lithuania \\ ${ }^{3}$ Vilnius Gediminas Technical University, Department of Biomechanics, Vilnius, Lithuania \\ ${ }^{4}$ Vilnius Gediminas Technical University, Department of Mathematical Statistics, Vilnius, Lithuania \\ ${ }^{5}$ Vilnius College of Higher Education, Vilnius, Lithuania \\ ${ }^{6}$ Centre of Radiology and Nuclear Medicine, Vilnius, Lithuania \\ ${ }^{7}$ Vilnius University, Faculty of Medicine, Vilnius, Lithuania \\ ${ }^{8}$ Vilnius University, Department of Pathology, Forensic Medicine and Pharmacology, Vilnius, \\ Lithuania \\ ${ }^{9}$ National Center of Pathology, Vilnius, Lithuania \\ ${ }^{10}$ Vilnius University, Clinic of Infectious, Chest Diseases, Dermatovenerology and Allergy, Center of \\ Infectious Diseases, Vilnius, Lithuania \\ ${ }^{11}$ R.E. Kavetsky Institute of Experimental Pathology, Oncology and Radiobiology, Kyiv, Ukraine \\ ${ }^{12}$ Department of Microbiology, Tumor and Cell Biology, Karolinska Institutet, Stockholm, Sweden \\ *E-mail: arida.buivydiene@santa.It, Elena.Kashuba@ki.se \\ Received: September 10, 2016; in final form May 31, 2017 \\ Copyright (c) 2017 Park-media, Ltd. This is an open access article distributed under the Creative Commons Attribution License, which permits \\ unrestricted use, distribution, and reproduction in any medium, provided the original work is properly cited.
}

\begin{abstract}
The expression levels of the two novel oncoproteins uridine-cytidine kinase like-1 (UCKL-1) and mitochondrial ribosomal protein S18-2 (MRPS18-2) were assessed in samples of hepatitis C virus (HCV)-associated hepatocellular carcinoma (HCC) using immunohistochemistry. Tissue microarray (TMA) paraffin blocks were prepared from $42 \mathrm{HCC}$ tumor samples with the corresponding peri-tumor tissues and from 11 tissues of a liver with HCV-induced cirrhosis. We found that the UCKL-1 signal in the liver tissues of the peri-tumor zone in the HCC samples was stronger than that in cirrhosis $(50 \pm 49.44$ vs. $24.27 \pm 14.53 ; p=0.014)$. The MRPS18-2 expression was weak, and there was no differences between the groups $(p=0.26)$. Noteworthy, the UCKL-1 protein was expressed at higher levels in peri-tumor tissues in the cases of HCC recurrence; this was confirmed for 27 older patients $(63.78 \pm 9.22$ vs. $53.53 \pm 4.07$ years, $p<0.001)$, in parallel with enhanced UCKL-1 staining in former HCC nodules $(62.69 \pm 50.4$ vs. $26.0 \pm 30.19, p=0.006)$ and microvascular invasion $(p=0.02)$. A multivariate analysis of prognostic factors for HCC recurrence showed that the best predictive factors for these conditions were UCKL-1 expression in tumor, vascular invasion, and HCC treatment modality, other than liver transplantation (odds ratios: 1.029, 18.143 and 11.984, $R^{2}=0.633, p=0.002$ ). In conclusion, the high UCKL-1 expression might be a prognostic factor for HCC relapse, in combination with age and microvascular invasion. MRPS18-2 protein expression has no prognostic significance in the cases of $\mathrm{HCV}$-associated HCC.
\end{abstract}

KEYWORDS hepatitis C virus (HCV), hepatocellular carcinoma (HCC), recurrence of hepatocellular carcinoma, UCKL-1, MRPS18-2, prognostic factors.

\section{INTRODUCTION}

Liver cancer (predominantly $\mathrm{HCC}$ ) is the second-most deadly cancer for men worldwide [1]. HCC incidence in Nordic countries, including Lithuania, reaches up to $10 / 100,000$ inhabitants [2]. In developed countries, one factor that is responsible for the increased $\mathrm{HCC}$ incidence is $\mathrm{HCV}$ [3]. In Lithuania, anti-HCV prevalence in adults stands at about 2.78\% [4]. HCV-induced HCC development is a multi-step process that may last 20-40 years and involves chronic hepatic inflamma- 
tion, progressive liver fibrosis, initiation of neoplastic clones, and tumor progression in a carcinogenic tissue microenvironment [5]. Noteworthy, eradication of $\mathrm{HCV}$ reduces, but does not eliminate, the risk of $\mathrm{HCC}$ development, especially when advanced hepatic fibrosis has already originated [6, 7]. It becomes difficult then and hardly manageable to follow patients at early-stage asymptomatic HCV-induced cirrhosis. Thus, it was discovered in a population-based study that less than $20 \%$ of patients with cirrhosis who had developed HCC were subject to regular monitoring [8]. Therefore, prognostic markers are now being actively developed to stratify $\mathrm{HCV}$ patients into clearly defined risk groups. Successful employ of these predictors in clinical practise could improve the clinical management of these patients [9]. Additionally, even with a successful $\mathrm{HCC}$ treatment by liver transplantation, liver resection, or radiofrequency-induced thermotherapy (RFITT), high risk of HCC recurrence persists $[7,8]$. The recurrence rate of $\mathrm{HCC}$ is estimated at $70 \%$ after 5 years of liver resection [10]. The validated prediction markers of recurrence are the tumor size, multifocality, macroscopic and microscopic vascular invasion, as well as poor differentiation [11].

It is widely accepted that malignant transformation of liver cells is stimulated by various factors. However, studies on the mechanisms of HCV-induced cell transformation are inhibited by the lack of animal and cell models. Obviously, better understanding of molecular mechanisms would help us identify new diagnostic and/or prognostic markers, most importantly, for the early detection of HCC [11]. This would allow us to develop better approaches to clinical treatment.

Usually, the molecular mechanisms that are responsible for virus-induced cell transformation include the inactivation of the two tumor suppressor protein pathways: i.e., the p53 (TP53) and retinoblastoma (RB) pathways $[12,13]$. There is little doubt that other proteins can play an important role in cell transformation: for example, the putative human enzyme UCKL-1 that is involved in cellular nucleotide metabolism $[14,15]$ and the new oncoprotein MRPS18-2 that can bind RB $[13,16,17]$. There are no data on the expression of both of these proteins in $\mathrm{HCC}$, and we asked ourselves the question of whether the UCKL-1 and MRPS18-2 expressions in HCC tissues could be used as prognostic markers for the course of the disease in HCV-bearing patients.

\section{EXPERIMENTAL}

\section{Patient samples}

The retrospective cohort study was conducted at Vilnius University Hospital Santariskiu Klinikos, Vilnius, Lithuania, according to the guidelines of the Helsin- ki Declaration. The study was approved by the Vilnius Regional Biomedical Research Ethics Committee (158200-13-698-224, from 2013-11-12). The HCC tumor and the corresponding peri-tumor (normal) liver tissue samples were collected from 53 patients who had undergone liver transplantation, liver resection, or RFITT for a complicated chronic HCV infection. Tissue sections from $42 \mathrm{HCV}$ positive cirrhotic patients with $\mathrm{HCC}$ and 11 samples from transplanted HCV cirrhotic patients without HCC, as a control group, were analyzed. All the specimens are preserved at the National Lithuanian Center of Pathology. A histological activity index (HAI) was scored, according to $\mathrm{K}$. Ishak et al., and liver fibrosis was assessed, according to METAVIR [18-20]. In $\mathrm{HCC}$ cases, tumor differentiation and microvascular invasion were evaluated.

\section{Analysis of UCKL-1 and MRPS18-2 expression}

in HCC and liver tissue specimens

Tissue samples after surgery, hepatic resection, and/ or liver transplantation were fixed in a buffered $10 \%$ formalin solution. Expression of the UCKL-1 and MRPS18-2 proteins was performed by immunohistochemistry (IHC) on tissue microarrays (TMAs) constructed of paraffin-embedded tissues, selected by the pathologist. Cores one millimeter in diameter were punched from the selected areas. Paraffin sections of the TMAs were cut ( $2 \mu \mathrm{m}$ thick), dewaxed, deparaffinized, and rehydrated. Epitopes were heat-activated in a EnVision FLEX target retrieval solution for $20 \mathrm{~min}$, while the $\mathrm{pH}$ of the buffer was low for UCKL-1 and high for MRPS18-2. The samples were cooled at room temperature for $15 \mathrm{~min}$. A two-step IHC procedure was performed with the EnVision FLEX detection system (DAKO), using an automatic staining Link instrument (DAKO). The primary anti-UCKL-1 (diluted $1: 200$ ) and anti-MRPS18-2 (diluted 1:150) antibodies (Sigma-Aldrich) were applied for 60 and $30 \mathrm{~min}$, respectively. The secondary antibody FLEX/HRP (DAKO) was applied for $20 \mathrm{~min}$. The peroxidase enzyme was then visualized with $3,3^{\prime}$-diaminobenzidine, tetrahydrochloride, and hydrogen peroxide. Hematoxylin was used as a counterstain for $10 \mathrm{~min}$. Visual evaluation of the UCKL-1 and MRPS18-2 signals was performed by an experienced pathologist. Each spot was graded individually. The UCKL-1 and MRPS18-2 cytoplasmic reactions were considered as negative if no positive cells were observed. If a MRS18-2 signal was detected mainly in the perinuclear cytoplasm, this was noted in the table of results, as well. The results of IHC reactions were evaluated semiquantitatively, by counting the number of positively stained cells in 1,000 analysed cells as a specified percentage - a label index (LI\%). LI values lower than the median expression of the marker 
Table 1. Demographic, clinical, and laboratory characteristics of patient groups

\begin{tabular}{|c|c|c|c|}
\hline Characteristics & $\begin{array}{c}\text { HCC } \\
(n=42)\end{array}$ & $\begin{array}{c}\text { Non-HCC } \\
(n=11)\end{array}$ & $p$-value \\
\hline $\begin{array}{c}\text { Follow up, mean } \pm \\
\text { SD*, years }\end{array}$ & $2.82 \pm 1.76$ & $5.27 \pm 2.49$ & $<0.005$ \\
\hline $\begin{array}{c}\text { Age, mean } \pm \text { SD, } \\
\text { years }\end{array}$ & $60.1 \pm 9.29$ & $49.42 \pm 9.29$ & 0.001 \\
\hline $\begin{array}{c}\text { Gender, count } \\
\text { (rate, \%): }\end{array}$ & $\begin{array}{c}16(38.1 \%) / \\
26(61.9 \%)\end{array}$ & $\begin{array}{c}4(36.4 \%) / \\
7(63.6 \%)\end{array}$ & 0.917 \\
\hline Women/ Men & BMI, mean \pm SD, \\
kg/m (m) $^{2}$ & $26.32 \pm 4.61$ & $26.75 \pm 4.18$ & 0.774 \\
\hline $\begin{array}{c}\text { HCV genotype (GT*): } \\
\text { GT-1, count (rate, \%) } \\
\text { GT-2, count (rate, \%) } \\
\text { GT-3, count (rate, \%) }\end{array}$ & $\begin{array}{c}27(64.3) \\
3(7.1)\end{array}$ & $\begin{array}{c}12(28.6) \\
0(01.8)\end{array}$ & 0.314 \\
\hline
\end{tabular}

*SD - standard deviation.

were considered as low, and if a LI value overran the median expression it was considered as high.

In addition, demographic information (age, body mass index (BMI), gender), laboratory data on the $\mathrm{HCV}$ infection ( $\mathrm{HCV}$ genotype (GT)), the cumulative size of $\mathrm{HCC}$ assessed radiologically, the HCC treatment modality (liver transplantation, liver resection or RFITT), and the time period of follow-up were evaluated for each patient.

\section{Statistics}

A statistical analysis was performed using the IBM SPSS 19.0 statistical program. The KolmogorovSmirnov test was used to assess data normality. Group differences were determined using the Student $t$ test when data distribution was normal: in other cases, the Mann Whitney and the Kruskal-Wallis criteria were used. $\chi^{2}$ tests were conducted for the categorical variables. To establish a connection between categorical variables, the Spearman correlation coefficient was calculated. A logistic regression model was constructed in order to investigate the association between the intensity of the UCKL-1 and MRPS18-2 signals in the $\mathrm{HCC}$ and microvascular invasion, the HCC treatment modality, and HCC recurrence after treatment. All hypotheses were verified with a selected significance level of $p<0.05$.

\section{RESULTS AND DISCUSSION}

\section{Characterization of patients}

Forty-two out of the 53 patients had developed the HCV-associated HCC and received treatment; 11 patients were diagnosed only with HCV-induced cir-
Table 2. Histological and immunohistochemical differences in liver tissue samples in groups

\begin{tabular}{|c|c|c|c|}
\hline Characteristics & $\begin{array}{c}\text { HCC } \\
(n=42)\end{array}$ & $\begin{array}{c}\text { Non-HCC } \\
(n=11)\end{array}$ & $p$-value \\
\hline $\begin{array}{c}\text { HAI, } \\
\text { mean } \pm \text { SD }\end{array}$ & $6.71 \pm 1.49$ & $6.64 \pm 2.34$ & 0.892 \\
\hline $\begin{array}{c}\text { UCKL-1, } \\
\text { mean } \pm \text { SD, LI (\%) }\end{array}$ & $50 \pm 49.44$ & $24.27 \pm 14.53$ & 0.014 \\
\hline $\begin{array}{c}\text { MRPS18-2, } \\
\text { mean } \pm \text { SD, LI (\%) }\end{array}$ & $8.68 \pm 16.61$ & $15.00 \pm 15.17$ & 0.260 \\
\hline
\end{tabular}

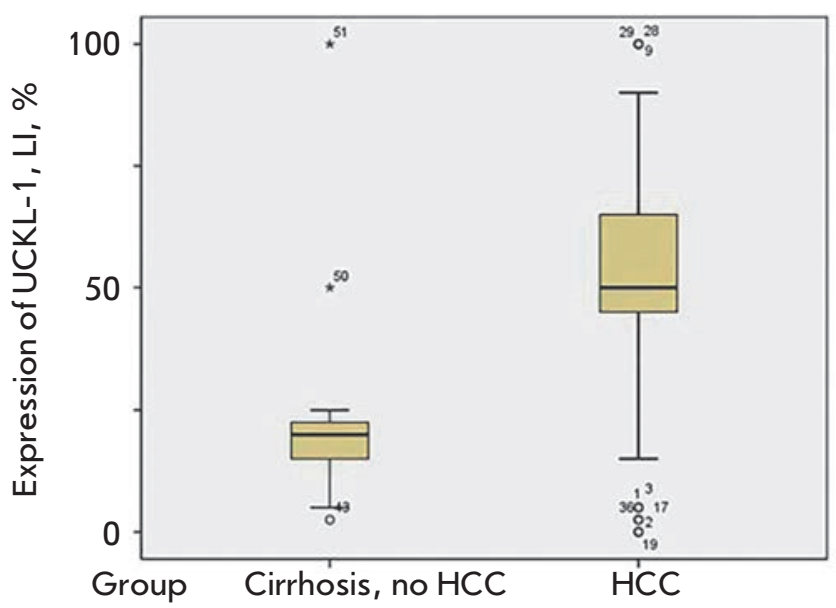

Fig. 1. The UCKL-1 expression in the liver tissue. Notice the significant increase in the UCKL-1 staining in samples with $\mathrm{HCC}$ in comparison with patients with cirrhosis without HCC

rhosis. All participants were followed up for at least 1 year at the Santariškiu Klinikos of Vilnius University Hospital; the HCC patients were observed for about $2.82 \pm 1.76$ years; and the patients with $\mathrm{HCV}$-induced cirrhosis - for $5.27 \pm 2.49$ years. Noteworthy, the HCC patients were significantly older than the individuals with cirrhosis $(p=0.001)$ : the mean age of the HCC patients was $60.1 \pm 9.29$ years, while the persons in the cirrhosis group were about $49.42 \pm 9.29$ years old. No differences in gender distribution (male/female ratio) in $\mathrm{HCC}$ and non-HCC (cirrhosis) groups were detected $(p=0.917)$. The BMI value was also similar in these groups $(p=0.774)$ (see Table 1$)$.

All participants had histologically confirmed advanced fibrosis, and HAI did not differ between the HCC and non-HCC groups ( $p=0.892)$ (Table 2).

The expression of UCKL-1 was high in the liver tissues of patients with HCC. We found that the UCKL-1 signal was stronger in the peri-tumoral liver tissue in HCC cases, compared with non-HCC (cirrhosis) cases ( $50 \pm 49.44$ vs. $24.27 \pm 14.53, p=0.014)$, as is presented in Table 2 and Figs. 1 and 2. 
On the contrary, the MRPS18-2 signal was observed rarely in the liver tissue and this low expression did not differ between the groups ( $p=0.26$ ) (see Table 2).

A description of the cohort of patients with HCC relapse

$\mathrm{HCC}$ recurrence in patients with $\mathrm{HCV}$-induced cirrhosis after curative treatment (liver transplantation, liver resection or RFITT) was confirmed radiologically in 27 of 42 patients. All patients were observed for at least 1 year before the diagnosis of $\mathrm{HCC}$ relapse (the mean observation time was $2.93 \pm 2.43$ ) (see Table 3 ). HCC relapse appeared usually after $2.76 \pm 1.3$ years. The recurrence rate $(62 \%)$ in the studied cohort and the time of relapse were similar to those reported earlier by other authors [10]. Moreover, the mortality rate in the relapsers was significantly higher than that in nonrelapsers (59.3 and $6.7 \%$, respectively, $p=0.001$ ) (see Table 3).

Importantly, the age of the patients in both groups differed significantly: $63.78 \pm 9.22$ years in those that showed a relapse and $53.53 \pm 4.07$ years in non-relapsers $(p<0.001)$ (see Table 3 ).

Noteworthy, women were diagnosed with HCC relapse more often than men: $87.5 \%$ (14 out of 16$)$ and $50 \%$ (13 out of 26 ), respectively ( $p=0.015$ ) (see Table $3)$. However, an absolutely larger number of men were diagnosed with HCC (26 men versus 16 women). It had also been reported earlier that older age and male gender are associated with an increased risk of HCC development in HCV cirrhotic patients [21, 22].

In our studied cohort of patients, no differences in $\mathrm{BMI}$ values, HAI, and HCC differentiation were detected between the groups of relapsers and non-relapsers (Table 3). We have to mention that, in the studied cohort, there were only two cases of poorly differentiated $\mathrm{HCC}$ (grade G3) in the group of relapsers and no G3 cases in the non-relapsers. Probably, this is one reason

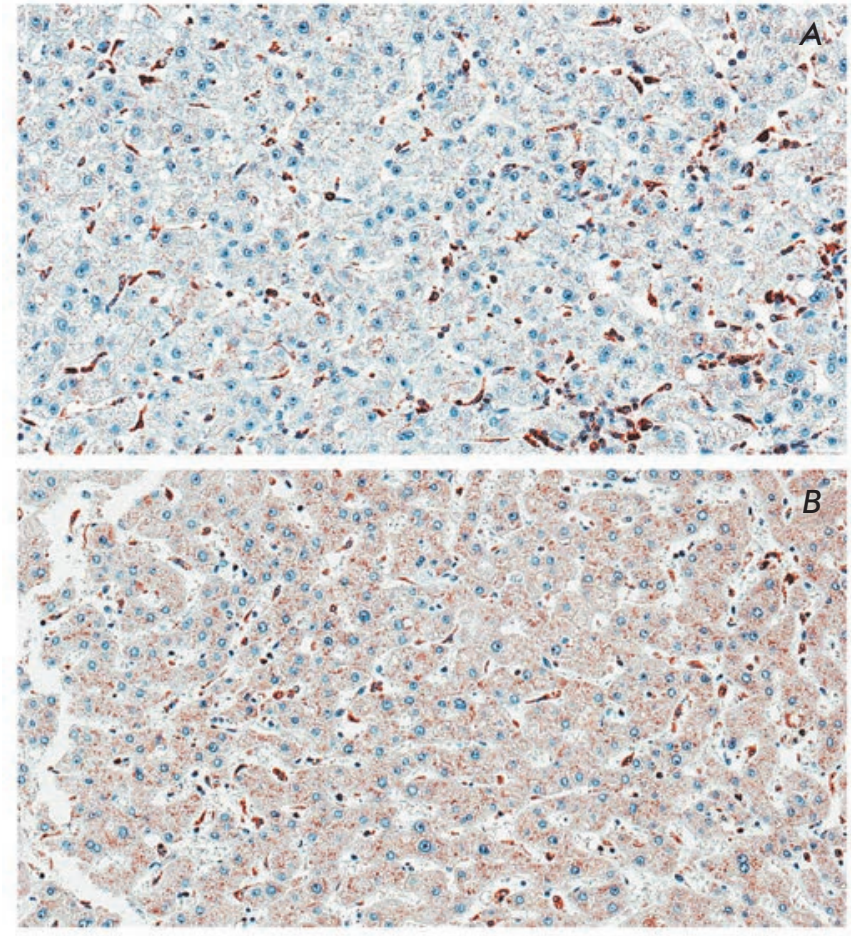

Fig. 2. The UCKL-1 cytoplasmic expression in liver tissue. Notice that the UCKL-1 cytoplasmic signal was significantly lower in the hepatocytes (expression was observed in $40 \%$ of the cells) of a cirrhosis patient $(A)$ in comparison with the UCKL-1 signal in 100\% of the peri-tumor hepatocytes of a HCC patient (B). Objective $\times 40$

why in our case the histological differentiation grade was not associated with HCC recurrence, contrary to published data [23].

When microvascular invasion was observed, HCC recurrence was diagnosed significantly more often $(p=0.02$, Table 4$)$. As a rule, tumors were larger in HCC

Table 3. Characteristics of patient groups with and without $\mathrm{HCC}$ recurrence

\begin{tabular}{|c|c|c|c|}
\hline Characteristics & $\begin{array}{l}\text { HCC recurrence } \\
\quad(n=27)\end{array}$ & $\begin{array}{c}\text { no HCC recurrence } \\
(n=15)\end{array}$ & $p$-value \\
\hline Lethality, count (rate, \%) & $16(59.3)$ & $1(6.7)$ & 0.001 \\
\hline Gender, count (rate, \%): -women/men & $14(51.9 \%) / 13(48.1 \%)$ & $2(13.3 \%) / 13(86.7 \%)$ & 0.015 \\
\hline BMI average $\pm \mathrm{SD}, \mathrm{kg} / \mathrm{m}^{2}$ & $27.05 \pm 4.88$ & $25.3 \pm 4.01$ & 0.245 \\
\hline
\end{tabular}


Table 4. Histological differences in liver tissue samples in $\mathrm{HCC}$ recurrence and non-HCC recurrence groups

\begin{tabular}{|c|c|c|c|}
\hline Characteristics & $\begin{array}{c}\text { HCC recurrence } \\
(n=27)\end{array}$ & $\begin{array}{c}\text { no HCC recurrence } \\
(n=15)\end{array}$ & $p$-value \\
\hline HAI, mean \pm SD, count & $6.89 \pm 1.19$ & $6.4 \pm 1.92$ & 0.381 \\
\hline HCC size, mean \pm SD, mm & $50.44 \pm 17.831$ & $41.47 \pm 20.757$ & 0.558 \\
\hline HCC grade of differentiation & & & 0.64 \\
-G1, count (rate, $\%)$ & $6(23.07)$ & $1(6.67)$ & \\
-G2, count (rate, $\%)$ & $18(69.23)$ & $14(93.33)$ & 0.02 \\
\hline -G3, count (rate, $\%)$ & $2(7.69)$ & $2(13.33)$ & \\
\hline Vascular invasion, count (rate, $\%)$ & $13(50)$ & & \\
\hline
\end{tabular}

relapsers (50.44 $\pm 17.83 \mathrm{~mm}$ vs. $41.47 \pm 20.76 \mathrm{~mm})$, but these differences were not statistically significant $(\mathrm{Ta}$ ble 4). Thus, in our study the microvascular invasion, proven histologically, was an independent predictive factor of a lower disease-free survival rate. Actually, tumor size and vascular invasion are well-known predictive factors of HCC recurrence [24, 25]. The studied cohort in the present paper was rather small, and that could be the reason why the size of the HCC nodules did not differ significantly between relapsers and nonrelapsers, even when such a trend was observed.
The high expression of UCKL-1 and

MRPS18-2 in HCC tissues

Comparing the expression of UCKL-1 and MRPS182 proteins in HCC nodules, a significantly stronger UCKL-1 signal was observed in HCC relapsers compared with non-relapsers: $62.69 \pm 50.4$ and $26.0 \pm 30.19$, respectively $(p=0.006)$. We have to emphasize that, at the same time, in the peri-tumor liver tissue no dramatic differences in UCKL-1 staining were detected when relapsers and non-relapsers were compared (Fig. 3 and Table 5). Hence, the UCKL-1 expression levels
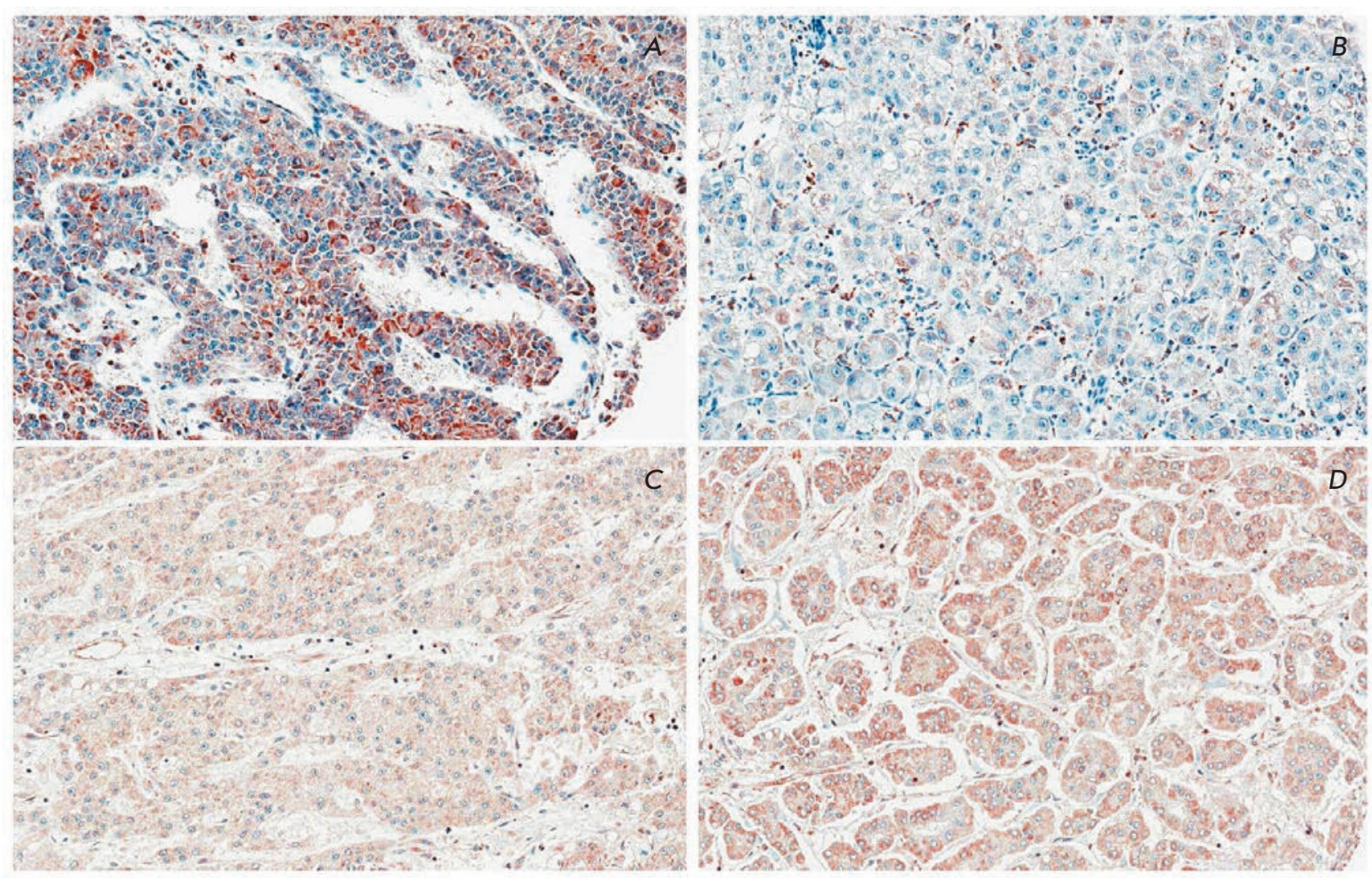

Fig. 3. The UCKL-1 and MRPS18-2 expression pattern in cancer tissues. Notice that the UCKL-1 cytoplasmic signal was significantly higher in the HCC samples of relapsers $(A)$ in comparison with the UCKL-1 signal in non-relapsing HCC $(B)$. The MRPS18-2 signal was strong in cancer tissues, regardless relapsing $(C)$ or non-relapsing $(D) \mathrm{HCC}$. Objective $\times 40$ 
Table 5. Immunohistochemical differences in liver tissue samples in groups of patients with and without HCC recurrence

\begin{tabular}{|c|c|c|c|}
\hline Characteristics & $\begin{array}{c}\text { HCC recurrence } \\
(n=27)\end{array}$ & $\begin{array}{c}\text { no HCC recurrence } \\
(n=15)\end{array}$ & $p$-value \\
\hline UCKL-1, mean \pm SD, LI (\%) & $49 \pm 32.44$ & $50.27 \pm 14.53$ & 0.510 \\
\hline MRPS18-2 in liver tissue, mean \pm SD, LI (\%) & $9.42 \pm 18.239$ & $7.40 \pm 13.835$ & 0.583 \\
\hline UCKL-1 in HCC nodule, mean \pm SD, LI $(\%)$ & $62.69 \pm 50.4$ & $26 \pm 30.19$ & 0.006 \\
\hline MRPS18-2 in HCC nodule, mean \pm SD, LI (\%) & $78.08 \pm 54.54$ & $61.67 \pm 60.52$ & 0.378 \\
\hline
\end{tabular}

Table 6. Logistic regression

\begin{tabular}{|c|c|c|c|c|c|c|}
\hline Characteristics & $\mathrm{B}$ & SE & Wald & DV & $p$-value & $\operatorname{Exp}(B)$ \\
\hline UCKL-1 in HCC & 0.029 & 0.013 & 5.022 & 1 & 0.025 & 1.029 \\
\hline Vascular microinvasion & 2.898 & 1.176 & 6.072 & 1 & 0.014 & 18.143 \\
\hline HCC treatment modality (transplantation->resection->RFITT) & 2.484 & 0.933 & 7.084 & 1 & 0.008 & 11.984 \\
\hline Constant & -6.316 & 2.178 & 8.413 & 1 & 0.004 & 0.002 \\
\hline
\end{tabular}

Note. B - regression coefficient, SE - standard error, Wald - Wald statistics value, DV - the dependent variable (1 for $\mathrm{HCC}$ recurrence), $\operatorname{Exp}(B)-$ odds ratio.

might have a prognostic value in terms of HCC occurrence and recurrence.

At the same time, the MRPS18-2 expression was several folds greater in the HCC nodules than in the unaffected liver, but no differences were observed between HCC relapsers and non-relapsers (Table 5). Therefore, the levels of MRPS18-2 could be considered as lacking prognostic significance for patients with $\mathrm{HCV}$ cirrhosis.

The high expression of UCKL-1 in HCC nodules can be a prognostic factor of $\mathrm{HCC}$ relapse

As was expected based on the data published earlier [26], the method of HCC treatment on its own had a significant predictive value of $\mathrm{HCC}$ recurrence: in the case of liver transplantation, the $\mathrm{HCC}$ recurrence rate was significantly lower than that after liver resection or RFITT - the were the only cases of HCC recurrence after liver transplantation (Table 3).The high rate of tumor recurrence after surgical resection and RFITT corresponded to the data in the literature [27].

After a multivariate analysis of prognostic factors for HCC recurrence was performed, we could conclude that the most significant variables were the levels of UCKL-1 expression in tumor nodes, vascular invasion, and the modality of the primary HCC treatment (other than liver transplantation) with odds ratios of 1.029 , 18.143 , and 11.984 , respectively $\left(R^{2}=0.633, p=0.002\right)$ (Table 6). As has already been mentioned, the expres- sion levels of MRS18-2 and the differentiation of HCC could not be predictive factors for $\mathrm{HCC}$ relapse.

Thus, the addition of the expression levels of UCKL1 as a predictive factor for the risk of $\mathrm{HCC}$ relapse resulted in a better prognosis of the course of the disease. A higher UCKL-1 expression in HCC nodules can be indicative of a higher risk of $\mathrm{HCC}$ relapse after curative treatment, especially if the treatment was not liver transplantation.

MRS18-2 was expressed at significantly higher levels in HCC nodules, compared with normal liver tissues, but it was not predictive of $\mathrm{HCC}$ recurrence.

These promising results regarding the prognostic value of UCKL-1 in terms of HCC occurrence and recurrence should be confirmed in a larger prospectiveretrospective clinical study.

\section{CONCLUSIONS}

A high level of UCKL-1 expression in HCC nodules, in combination with microvascular invasion and $\mathrm{HCC}$ treatment modality (other, than liver transplantation), is a predictor of a higher risk of $\mathrm{HCC}$ recurrence.

This work was supported by the Swedish Cancer Society, matching grants from the Concern Foundation (Los Angeles) and the Cancer Research Institute (New York), the Ministry of Education and Science of Ukraine (No.0116U005456), and the Research Council of Lithuania (No.TAP-LU-15-003). 
REFERENCES

1. Torre L.A., Bray F., Siegel R.L., Ferlay J., Lortet-Tieulent J., Jemal A. // CA: Cancer JClinicians. 2015. V. 65. № 2. P. 87-108.

2. McGlynn K.A., London W.T. // Clinics Liver Disease. 2011. V. 15. № 2. P. 223-243, vii-x.

3. El-Serag H.B. // N. Eng. J. Med. 2011. V. 365. № 12. P. 1118-1127.

4. Liakina V., Valantinas J. // Med. Sci. Monitor: Internat. Med. J. Exp. Clin. Res. 2012. V. 18. № 3. P. PH28-PH35.

5. Goossens N., Hoshida Y. // Clin. Mol. Hepatol. 2015. V. 21. № 2. P. 105-114.

6. van der Meer A.J., Veldt B.J., Feld J.J., Wedemeyer H., Dufour J.F., Lammert F., Duarte-Rojo A., Heathcote E.J., Manns M.P., Kuske L, et al.// JAMA. 2012. V. 308. № 24. P. 2584-2593.

7. Bruno S., Crosignani A., Roffi L., De Lisi S., Rossi S., Boccaccio V., Zermiani P., Mondelli V., Maisonneuve P.// J. Hepatol. 2014. V. 60. № 1. P. S224.

8. Davila J.A., Morgan R.O., Richardson P.A., Du X.L., McGlynn K.A., El-Serag H.B. // Hepatology. 2010. V. 52. № 1. P. 132-141.

9. Hoshida Y., Fuchs B.C., Bardeesy N., Baumert T.F., Chung R.T. // J. Hepatol. 2014. V. 61. (1 Suppl.). P. S79-S90.

10. Waghray A., Murali A.R., Menon K.V.N. // W.J. Hepatol. 2015. V. 7. № 8. P. 1020-1029.

11. Colecchia A., Schiumerini R., Cucchetti A., Cescon M., Taddia M., Marasco G., Festi G.// World J. Gastroenterol. 2014. V. 20. № 20. P. 5935-5950.

12. Smirnova I.S., Aksenov N.D., Kashuba E.V., Payakurel P., Grabovetsky V.V., Zaberezhny A.D., Vonsky M.S., Buchinska L., Biberfeld P., Hinkula J., et al. // Cell. Oncol.: Official J. Internat. Soc. Cell. Oncol. 2006. V. 28. № 4. P. 177-190.

13. Darekar S.D., Mushtaq M., Gurrapu S., Kovalevska L., Drummond C., Petruchek M., Tirinato L., Di Fabrizio E.,
Carbone E., Kashuba E.// Oncotarget. 2015. V. 6. № 25. P. 21016-21028.

14. Ambrose E.C., Kornbluth J. // Apoptosis: Internat. J. Programmed Cell Death. 2009. V. 14. № 10. P. 1227-1236.

15. Kashuba E., Kashuba V., Sandalova T., Klein G., Szekely L. // BMC Cell Biol. 2002. V. 3. № 1. P. 1-12.

16. Kashuba E., Pavan Yenamandra S., Darekar S.D., Yurchenko M., Kashuba V., Klein G., Szekely L. // Proc. Natl. Acad. Sci. USA. 2009. V. 106. № 47. P. 19866-19871.

17. Shevchuk Z., Yurchenko M.Y., Darekar S.D., Holodnuka-Kholodnyuk I., Kashuba V.I., Kashuba E.V. // Acta Naturae. 2013. V. 5. № 1. P. 85-89.

18. Ishak K., Baptista A., Bianchi L., Callea F., De Groote J., Gudat F., Denk H., Desmet V., Korb G., MacSween R.N.M., et al.// J. Hepatol. 1995. V. 22. № 6. P. 696-699.

19. Bedossa P., Poynard T. // Hepatology. 1996. V. 24. № 2. P. 289-293.

20. Goodman Z.D. // J. Hepatol. 2007. V. 47. № 4. P. 598-607.

21. Llovet J.M., Burroughs A., Bruix J. // Lancet. 2003. V. 362. № 9399. P. 1907-1917.

22. El-Serag H.B., Rudolph K.L. // Gastroenterology. 2007. V. 132. № 7. P. 2557-2576.

23. Lauwers G.Y., Terris B., Balis U.J., Batts K.P., Regimbeau J.M., Chang Y., Graeme-Cook F., Yamabe H., Ikai I., Cleary K.R., et al. // Am. J. Surgical Pathol. 2002. V. 26. № 1. P. 25-34.

24. Wahab M.A., Shehta A., Hamed H., El Nakeeb A., Salah T. // Eurasian J. Med. 2014. V. 46. № 1. P. 36-41.

25. Llovet J.M., Schwartz M., Mazzaferro V. //Semin. Liver Dis. 2005. V. 25. № 2. P. 181-200.

26. Welker M.-W., Bechstein W.-O., Zeuzem S., Trojan J. // Transplant Internat. 2013. V. 26. № 2. P. 109-118.

27. Lim K.C., Chow P.K., Allen J.C., Siddiqui F.J., Chan E.S., Tan S.B. // Br. J. Surgery. 2012. V. 99. № 12. P. 1622-1629. 